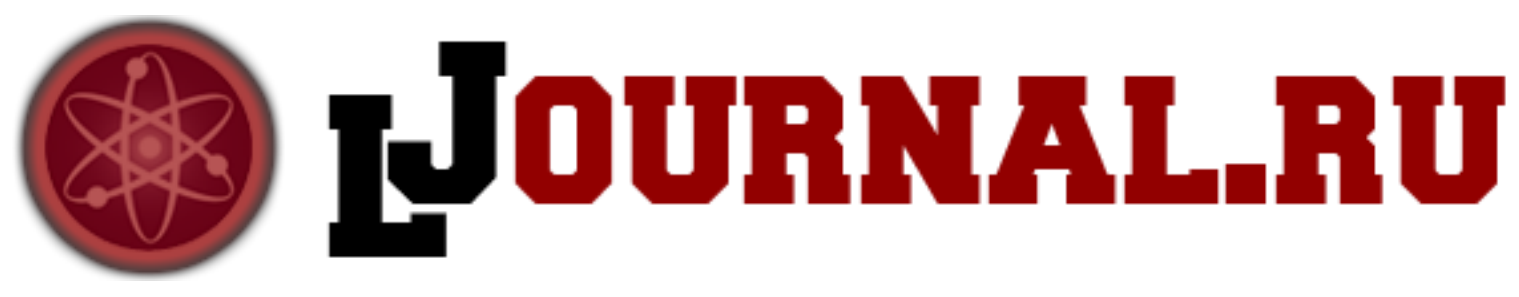

Гатилова А.B.

Национальный исследовательский Томский государственный университет

Томск, Россия

doi: 10.18411/1j2016-1-07

\title{
Анализ стратегических перспектив развития системы высшего образования в России
}

В рамках осуществляемой модернизации разворачивается невиданный по своим масштабам эксперимент. В русле обоснования «стратегических перспектив развития〉 ныне формируются следующие тренды:

1. ликвидация неэффективных ВУЗов и решительные меры по контролю качества образования, прекращения «торговли дипломами»;

2. практикоориентированность образовательных программ, их нацеленность на результат (performance improvement), востребованный рынком труда;

3. индивидуализация на основе формирования индивидуальных траекторий обучения;

4. управление знаниями через активное участие студентов в их поиске, хранении и обмене;

5. поддержка качества образования (performance support) через различные уровни доступа к информации (методическому обеспечению);

6. дистанционное обучение - расширение использования информационных технологий в учебном процессе и внедрение он-лайн программ;

7. «обучение в неформальной обстановке» (informal learning), в частности в процессе образовательных игр; 
8. использование новых коммуникаций - социальных медиа-блогов, социальных закладок, Youtube в обучении как средств обратной связи и демонстрации лекций;

9. использование реальных проблемных ситуаций (кейсов);

10.мобильное образование, включая мобильные обучающие платформы, планшеты, смартфоны.

В результате анализа обозначенных трендов выявляется перечень проблем, стоящих перед высшей школой в целом. Целесообразно эту совокупность проблем разделить на четыре блока в зависимости от ориентации и направленности: 1. Наука 2. Кадры 3.Учеба. 4. Инфраструктура.

\section{I. Наука}

- недостаток исследователей высокого уровня и международных взаимосвязей;

- недостаточная активность совместной (творческие коллективы) научной деятельности между ведущими вузами и подразделениями системы РАН;

- невысокая активность участия профессорско - преподавательского состава (ППС) в грантовой деятельности;

- небольшое количество публикаций в журналах, индексируемых в базах Web of Science и Scopus.

II. Kadpbl

- высокий средний возраст профессорско-преподавательского состава и отсутствие кадрового резерва;

- низкий уровень компетенций межкультурных коммуникаций у ППС.

III. Учеба

- недостаток международных сертифицированных образовательных программ, программ «двойного диплома», программ на иностранном языке;

- недостаточное взаимодействие с потенциальными работодателями;

- расширение подготовки по прикладным специальностям в ущерб традиционной фундаментальности классического университетского образования; 
- отсутствие маркетингового обеспечения образовательного процесса;

\section{IV. Инфраструктура}

- неразвитость институтов эндаумента и спонсорства;

- недостаток площадей и оборудованных рабочих мест для оказания образовательных услуг.

Стратегический подход к решению выявленных проблем может быть реализован посредством следующих направлений:

1. Разработка и реализация исследовательских проектов и образовательных программ, направленных на развитие качества высшего образования (создание новых типов программ, конкурсов, экспериментов).

2. Внедрение в практику управления механизмов участия и влияния на качество образования всех субъектов образовательной деятельности.

3. Организация экспертно-аналитического сопровождения образовательной деятельности и приглашение экспертов - практиков.

4. Разработка предложений по формированию образовательной политики, (портфель \пул образовательных программ).

5. Обеспечение формирования педагогических компетенций выпускников в целях эффективного удовлетворения кадровых потребностей вузов региона;

6. Развитие системы дополнительного профессионального образования, а также программ повышения квалификации и переподготовки сотрудников и преподавателей вузов региона по данному направлению.

Тогда стратегическими приоритетами развития высшего образования станут:

1. повышение качества образования через всестороннюю поддержку человеческого капитала всех категорий ППС; 
2. формирование портфеля образовательных конкурентоспособных программ в соответствии с приоритетным научным направлениям деятельности ВУЗов

3. обеспечение концентрации ресурсов на разработке общей научноисследовательской проблемы, созвучной выбранной стратегии ВУЗа;

4. отказ от профилизации бакалаврских программ и неэффективных магистерских программ;

5. расширение дистанционных форм обучения;

6. создание эффективной структуры управления системой образования в ВУЗе, обеспечивающей достижение целевых показателей. 